\title{
A Critical Investigation into the Role of Widows in Early Church Life
}

\author{
Angelo Nicolaides \\ Department of Philosophy and Applied Ethics \\ Faculty of Arts, University of Zululand \\ Kwa-Dlangezwa, South Africa \\ University of Zululand, South Africa \\ http//:orcid.org/0000-0002-2153-2853
}

Doi:

\begin{abstract}
A critical question to be asked in the modern world is whether or not women should have leadership roles in churches. Saint Paul teaches us that we should have a vision of a church that is unified and which embraces diversity. When he discusses the various gifts of grace within the church in Ephesians (4:11), he is by no means suggesting that the roles of the gifted are linked to gender. It is however also clear from the holy scriptures that no woman was selected to be an apostle. Nonetheless, the Eastern Orthodox Church recognizes that there were a number of woman who were equal in status to the apostles, inter-alia, Saint Helena and Saint Mary Magdalene. In the Graeco-Roman world of New Testament Palestine, religion operated in a highly paternalistic and patriarchal society in which there was often much debate on issues of sexuality and the belief that women per se were not suitable to serve in ecclesial roles was commonplace. When it came to widows however, they enjoyed somewhat of a special status and were able to serve in a particular manner which was deemed to be acceptable. The widows in the early Church provide a thought-provoking Christian character, which springs from their innate desire to do good deeds and from their austere practices that point to solid Christian discipleship even though they functioned honorifically. This article investigates what the Didascalia Apostolorum has to say concerning the status and function of widows in early church life. The Order of Widows which existed in the early Church decayed in importance at the advent of the fourth century, as numerous of its functions were adopted by deaconesses. If we accept that human beings have natures which are created in the imageo Dei, then women are invariably equal in their humanity to men. Why is it then that they are precluded from serving as priests or other ecclesial orders in various denominations? A historical-critical methodology was employed in this brief study making use of literature emanating from academic journals, theological books, early church documents and a range of online sources. This article hopefully enables the reader to develop a great understanding of early Christian widows as consecrated women, serving the Church and God.
\end{abstract}

Keywords: Gender, equality, ecclesial roles, widows, early Church.

\section{Introduction}

In the Old Testament as well as in the New Testament period, just as is the case today, widowhood presented a problematic time in a woman's life. A widow - אלמנות (heb. almanah) Xńpa (gk. chera), was generally neglected in the daily ministrations. It was especially stressful when a widow had a reduced ability to meet the financial needs of her remaining family. This was a common condition in the patriarchal society of the Levant. Widows habitually became a special teaching prospect for authors who sought to offer profound theological insights on how to live as God's people. Deuteronomy 16:11-14 shows us how God provided for widows 
so that they were not excluded but rather participated fully in the Feast of Weeks and the Feast of Tabernacles. In the Book of Lamentations we see the susceptibility of widows in society where the term "widow" was used to describe Jerusalem after Nebuchadnezzar destroyed the city : "1How lonely sits the city that was full of people! How like a widow is she, who was great among the nations! The princess among the provinces has become a slave! 2.She weeps bitterly in the night, Her tears are on her cheeks; Among all her lovers She has none to comfort her. All her friends have dealt treacherously with her; They have become her enemies" (Lamentations 1:1-32). The Old Testament informs us that God keeps caring for widows (Psalm 68:5; Proverbs 15:25). He is intensely concerned for them and $\mathrm{He}$ is protects them since he is "a father of the fatherless, a defender of widows... in his holy habitation" (Psalm 68:5). Having genuine sympathy and empathy with widows is a mark of true religion (Job 13:16).

In both the Old and New Testaments, widows are recurrently the foci of various miracles. A widow's best hope for sanctuary would be her son's ability to provide for her, assuming that she had one. As is the case today, widowhood represented an extremely demanding challenge in a woman's life. They were for the most part devoid of care and were clustered along with the fatherless, the poverty stricken and aliens. We do however find that widows fell under God's protective care (Deuteronomy 24:17, 21; Ezekiel 22:7; James 1:27). God also instructs that they should not be oppressed in any manner (Zechariah 7:10).

In the New Testament era, Jesus reprimanded teachers of the law for devouring widows' houses since they were vulnerable and helpless (Mark 12:38, 40). He cared for his widowed mother Mary (John 19:25-17), and he raised from the dead the son of the widow of Nain and returned him to his mother (Luke 7:11-17). Jesus utterly condemned those who sought to take advantage of widows (Matthew 23:24). The early church also cared for widows (Acts 6). Caring for them was so important that seven men of good character, full of understanding and the Holy Spirit, were designated to be responsible for caring for widows. In the New Testament era as indeed is the case now, the issue of women in the ministry in the Church remains a pressing one. Including women in the church's ministerial and also its sacramental orders is highly problematic for some churches and they are for the most part, happy with the status quo and readily and correctly, according to primal teachings, accept traditions dating back to antiquity. It is evident that in the early Church, women in fact often did occupy important positions, and especially the widows played a vital role. We also need to remember that contrary to what type of testimony one might expect in a patriarchal society, it was women who were the first believing witnesses to the glorious resurrection of Jesus Christ Our Lord. This fact clearly has a deeper significance to ponder on. We clearly need a more coherent approach to Biblical Hermeneutics and an end to finite reason and egoism which tend to give us distorted messages on God's intentions for humanity and males and females who are after all, each created in the imageo Dei.

\section{Methodological stance}

A historical-critical methodology was employed in this brief study making use of literature emanating from academic journals, theological books, early church documents and a range of online sources. At the outset the author wishes to assert that the Holy Bible is understood to be the authentic Word of God and a reliable record and it is the chief and authoritative means via which God reveals Himself to humanity. The Holy Spirit inspired the Bible writers thus the Holy Scriptures are an inseparable amalgamation of human and divine elements, neither of which should be accentuated to the abandonment of the other (see inter alia 2 Peter 1:21; Thessalonians 3:14; 2 Timothy 3:15; Hebrews 4:12). Orthodoxy believes that all Holy Scripture is inspired by God and came through the work of the Holy Spirit. The Holy Bible consequently transcends cultural background and serves as God's Word for all cultural, racial, and situational contexts and for all time. The inclusion of women in leadership roles has been 
studied by a wide range of modern scholars, and each of them wishes to somehow revise our understanding of the contribution of women in the church in the first few centuries of the Graeco-Roman world.

In this brief study, I sought to exposit the message of Paul relating to widows and others, and to discover the underlying major issues relating to them as offering a ministry in the early church period times. I thus used various primary texts, passages from the Holy Bible and academic articles and books as well as online sources to arrive at conclusions that were drawn. Where possible I endeavoured to ascertain the historical circumstances in which the idea relating to widows as ecclesial servants was formulated and understood. The relational property of personhood as an ethic of virtue in women is explored and historical and cultural factors are considered in an effort to contribute to understanding the role of widows in church service. This was followed by a careful evaluation of diverse viewpoints, past and present. While one's experience or a statement of Scripture may well be a divinely inspired record, not every single statement or experience is automatically normative for Christian behaviour in the current Christian denominational milieu. This study has limitations in that it focuses on only the role of widows, who assumed the title of deaconess and assumed vital pastoral functions according to the Didascalia Apostolorum.

\section{Background}

In the Graeco-Roman world, there was sharp delineation between men and women which in many ways paralleled the Hebrew notion that females were to be passive, silent and utterly obedient and above all exhibit humility. While Paul alludes to these aspects in his writings, it is noted that when he early church was operating as house congregations, women did take the lead in many cases and held a range of positions such as inter alia, being ministers and also missionaries. Once Constantine the Great (272-337 CE) converted to Christianity, he ceased the persecution of Christians and legalized Christianity, in the Roman Empire (Barnes, 2011; Pelikán, 1987). At this juncture, both civil and sacred spaces became blended areas, and ordained orders were no longer accepting women. Women became increasingly marginalized as Genesis 3 which accused women for the fall and viewed them as inferior beings, was flouted by especially Augustine of Hippo a respected theologian and philosopher (354-430 CE). Augustine did not accept as true that Adam was any less guilty of sin than Eve and he praised women and their role in society and in the Church (Clark, 1986). In his work the Tractates on the Gospel of John at Tractate 15, Augustine, remarks concerning the Samaritan woman in John 4:1-42, and he uses her as a figure of the Church in full agreement with the New Testament instruction that the Church is the bride of Christ. "Husbands, love your wives, as Christ loved the church and gave himself up for her." (Ephesians 5:25).

We often assume that only men have a vocation to serve the Church of God. It is however evident that various woman in the Early Church Served in ministries as deaconesses. Their roles varied in scope and included teaching and instructing and many were involved in the missionary actions of the church. Women were permitted to serve is apostolic preachers and a number of them were involved in caring for those who were ill and had need of spiritual support. They also cared for refugees, those who were persecuted and prisoners. Many mediated when there were rifts between members of the church, and they cared for the physical, emotional and spiritual needs for people in important ways (Grenz \& Muir Kjesbo, 1995). Women, including virgins and widows were called upon by Saint Ambrose to strengthen the moral fabric of a Roman society that had been disrupted by the Emperor Julian (361- 363 BCE) who relinquished Christianity and wanted to reinstate pagan worship (Nicolaides, 2014).

Some were involved in prayers and intercessory acts while others offered guidance and spiritual support to those requiring it as individuals or even families (Evdokimov, 1994). 
Thurston (1908) states that in their primary institution the deaconesses were envisioned to perform the same charitable offices for women, which were executed for the men by the deacons. There were some differences in function such as in instruction and baptism of catechumens, in which case their duties were more spiritual in orientation (Bradshaw, 2012). The universal pervasiveness of baptism by immersion and the anointing of the entire body which preceded it rendered it a matter of respectability that in this important ceremony for believers, the functions of the deacons would be discharged by women (Thurston, 1908). Women attended to the needs of other women in an assortment of ways, including instructing catechumens, playing a supporting role in women's baptisms and they were also tasked with welcoming women into church services (Wharton, 1987). Virtue needs to be displayed in leadership so that all people can be treated well and equally irrespective of gender (Onumah \& Nicolaides, 2021).

In the Teaching of the Apostles which is a work of the early $3^{\text {rd }}$ century CE there is reference to deaconesses which stated that "...the Deacon stands in the place of Christ and do you love him. And the deaconess shall be honoured by you in the place of the Holy Spirit" (Connolly, 1929). The Latin title Didascalia Apostolorum means the Teaching of the Apostles, and in Syriac it is: "Didascalia, that is, the teaching of the twelve Apostles and the holy disciples of our Lord". The Didascalia Apostolorum at no time touches speaks of dogma but is rather concerned with practice. This is different to the Didache, as the key focus of that work relates to moral matters, liturgical practices and church organization. There were women who served as deaconesses (Greek diakonisses) which means a servant or helper and this transpired often in the Christian New Testament of the Bible (Martimort, 1986). Diakonos (Gk.) is a masculine word, and was used by Paul concerning his ministry. Phoebe is the only woman to be named "deacon" by Paul (Hammer, 2009). The Byzantine church permitted women to become deaconesses and they enjoyed liturgical as well as some limited pastoral functions within the church (Karras, 2004). Ordination to the diaconate was also seen as fitting for women responsible for the women's choir which was an important liturgical duty and some accept as true that women were also permitted to preside over the Eucharist, however this practice has been refuted by numerous scholars (Coyle, 1993). Swan, 2001). Paul mentions some women as being diakonisses (deaconesses) in his letters (Campbell, 2009; McCarty, 2010) and their ministry is also cited by early Christian writers such as Clement of Alexandria (Stromata) and Origen (Migne PG XIV). Various scholars maintain that women played a substantial role in building and sustaining the Church, as deaconesses, patrons, prophets, and martyrs in the service of the Lord (Kaveny, 2005). In the Orthodox Christian tradition, Holy tradition confers upon us an understanding of what we need to hear and how we should continue to practise what we hear read. Thus, when Christ calls on John to care for His 'mother', the Virgin Mary, he is teaching us to care for widows (Nicolaides, 2014).

The East Roman Empire included women as deaconesses and the $4^{\text {th }}$ century CE Church Fathers including inter alia, Gregory of Nyssa (Migne PL 46), Basil of Caesarea (St. Basil Letters, 1930) and John Chrysostom (Migne PG 62) accepted the ministry of women as ordained deacons. Nicolaides (2010) informs that all, male and female alike, were and are part of the people of God. According to Meeks (1983) Paul's church enjoyed a concentrated, practically familial bond between all its adherents irrespective of gender.

\section{The Pauline stance}

The apostle Paul possessed great confidence in the veritas and importance of his message in the weltanschauung and pluralistic religions of his era. His confidence was linked to his gnosis of the weak human condition before the Creator. A Pauline analysis certainly aids us in our quest to better understand the lives, ideas and cultural biases in society in his day relating to the notion of gender. His understanding of the human condition before God was 
linked to his faith in the truth, and also the critically important value of the gospel he disseminated.

Through Paul, the care of widows indubitably flowed out of the Jerusalem congregation into other Christian congregations, and became increasingly Gentile in orientation. Roman society had large numbers of widows, and the Roman brashness toward widows guaranteed that Christian communities would always have a chance to offer care for them. Thus some were inducted into the Order of Widows. An important church directive was that a widow needed to be "truly a widow," in other words a widow had to be over the age of sixty without an support from either immediate or extended family members (Wessel, 2017).

The involvement of a number of women in the formation of the Philippian church is significant (Acts 16:11-40). Paul starts the church in Philippi with a group of women who were congregated for prayer outside the city gate (Acts 16:13-15). Lydia was one of the leaders of the group and her home became the focus of the Philippian church (Acts 16:14-15, 40). Acts also provides us with importance of Priscilla (Acts 18:2,18, 26). Priscilla and her husband Aquila, tutored Apollos, who became a renowned teacher in the church (Acts 18:26; 1 Timothy 2:12). Paul calls all Philippian Christians to live a life worthy of the gospel of Jesus Christ. In this he does not speak of any type of unique and private holiness, but rather calls for a unified mission to serve God, irrespective of gender. He urges male and female to stand firm in one spirit with one mind striving side by side for the faith of the gospel (Philippians 1:27). There should thus be total love in any community of faith. One cannot purport to love God and hate his brother (sister) (1 John 4:20). Holiness and also purity of heart are essential elements for all human beings to strive for, irrespective of their gender.

It may be argued that 1 Corinthians 14:34-35 supports the notion that men have higher status than women. Paul states "Let your women keep silent in the churches, for they are not permitted to speak; but they are to be submissive, as the law also says. And if they want to learn something, they should ask their own husbands at home; for it is shameful for women to speak in church." Women were essentially not to indulge in conversations during public worship (Dei \& Osei-Bonsu, 2015; Davis, 2005). This is fully supported by Warfield (1919) who argues that Paul was telling women to refrain from speaking in church. If we carefully interrogate how Paul conducted himself towards women while on his missionary trips, it becomes very difficult for us to comprehend that he would prohibit females from serving in leadership roles in the church. In 1Timothy 2:11-12, Paul speaks of the higher status of men when he says "A woman should learn in quietness and full submission. I do not permit a woman to teach or to have authority over a man; she must be silent." but he in fact very often spoke of the oneness of human beings (1 Corinthians 12:12-14; Ephesians 4:46). In any event, there is really no valid biblical, theological, or traditional endorsement of the position either to exclude or to include women in the Gospel Ministry as ordained ministers (Dei \& Osei-Bonsu, 2015). In terms of The Canons of Hippolytus which is an allembracing variant and version of the Apostolic Tradition compiled in Egypt in the $4^{\text {th }}$ century, widows were evidently a part of the ordained clergy (Stewart, 2015). The modus of appointment and even ordination service of widows twinned those of deacons, bishops and presbyters. The widows are in fact termed presbyteresses (female presbyter) and on six occasions they are referred to as "the widows who sit in front." It is also evident that during communion, they stood at the altar, adjacent to the bishops, presbyters and deacons, and thus they were well within the veil like modern day iconostasis, that partitions off the laity (Botte, 1946).

Galatians 3:28, like Acts 2, is often viewed as a basis for having women in the ministry. However the critics of the notion of women serving ministry repeatedly argue that Galatians 3:28 makes reference to only the spiritual reality of equivalent access to God through one's faith in Jesus Christ. In Galatians 3:28, Paul upholds that "There is no longer Jew or Greek, there is no longer slave or free, there is no longer male and female; for all of you are one in 
Christ Jesus." If we consider his greetings to women and in accepting Phoebe as a deaconess, it is most likely that Paul supported the notion of equality between genders (Lee, 2021). Pagels (1989) suggests that any antifeminist components in Paul's view such as in the letters to the Colossians and to the Ephesians, do not correctly reflect Paul's high esteem towards women, but could in fact also be "pseudo-Pauline" forgeries. Leonhard (2006) also agrees that Paul would not have treated women such Prisca, Phoebe and Junia the way he did, as Church leaders and apostles, if they were not permitted to express themselves in public settings. If we assume a complementarians stance, we can argue that women and men are indeed of equal worth before God, because both were created in the Imago Dei, but have diverse functions and responsibilities in marriage as well as life in general (Johnson, 2006). Many of the women in New Testament times were not relegated to inferior roles in the church or society, but were in fact socially powerful, including Phoebe, who took care of Paul (Romans 16:1-2), or even Lydia, the merchant who was a very willing patroness of the apostles (Acts 16:14) (Meeks, 1983). the events of Acts 2 have been one of the major arguments in favour of women in ministry.

Beside the outstanding achievements of individual women stood the ministry of consecrated women in specialized orders. These orders included ecclesial widows, virgins, presbyteresses and deaconesses. Sometimes such women were formally ordained and sat with the rest of the clergy in front of the congregation. We need to recall here that in Luke 8:23, underprivileged women accompanied the Lord during his Galilean ministry and they possibly fashioned the commencement of the Order of Widows. The Greek term cheira (widow) might refer to any woman who found herself in problematic settings. In the Clementine Recognitions and Homilies, $3^{\text {rd }}$ century, St. Peter, appointed elders and deacons and systematized an Order of Widows (Kroeger, 1988). Widows were maintained by the gifts of worshippers made to bishops, and were in turn anticipated to pray for their sponsors as well as all other members of the church. Their range of limited duties and qualifications for their role were established based upon the instructions provided in 1 Timothy 5.

\section{Specific mention of women by Paul in his letters}

Paul refers to three categories of women 1 Timothy 5 that were important in the community. (Quinn \& Wacker, 2000). Firstly, there was the real widow, who was married only once and met the other credentials listed for ministry (1 Timothy 5:3, 5-10). Secondly, there were younger widows (1 Timothy 5:11-15), and thirdly, other widows who had progenies to care for them (1 Timothy 5:4,16). Paul mentions thirteen women by name who were his co-workers in spreading the faith. This demonstrates that women indeed practiced in the church. Each case offer us a good idea that women did indeed contribute to gospel ministry, along with men. "Paul's common terminology made no distinctions in roles or functions between men and women in ministry" (Scholer, 1983/84). Others such as for example Luke, also mentioned a woman by the name of Anna, in Luke 2:36-38 whom he depicts as being a prophetess who prayed and fasted constantly in the Temple most likely due to not have a family or being a widow (Tyson, 1992). Anna is the only woman in the New Testament to explicitly be termed a prophetess, illustrating the important roles women could attain (Seim, 1994). Seim also argues that Anna represents a prototypical widow "with roots in Jewish types of piety such as exemplified by Judith, and representative of the widows in the Christian community in a way that apparently harmonizes well with the criteria of the true widow set out in 1 Timothy $5 . "$

Using the example of Anna St. Ambrose displays the life of widows should be like, and he expresses the opinion that she was an example of chastity. He uses this to argue that there are three degrees of the same virtue of chastity. One kind is that of married woman, a second is that of widowhood, and third is that of virginity, and he used examples of Mary, Anna, and Susanna to support this notion. He however also states that virginity is superior to any of the 
others, and argues that a widow should take great care to preserve her good name (Ambrose, Concerning Widows).

Anna and others exhibited devout observances of prayer and fasting, and she and others in the New Testament era were young widows who never remarried. From its prior sorry status, widowhood could allow a woman to attain valued characteristics and ultimately great honour (Moore, 2019). Reid (1996) asserts that "Anna is a prototype of what would later develop into a clerical order of consecrated widows whose duties included prayer, fasting, visiting and laying hands on the sick, making clothes, and doing good works" in alignment with the duties required of widows by the Didascalia Apostolorum. Also "Anna's advanced age and the fact of Anna having only one husband were among two of the requirements for enrolling in the order of widows in the early Church" (Moore, 2019). Widows needed to be dedicated to a life of prayer and they were selected to be enrolled in the Order of Widows. They needed to be dedicated to "community service and conduct charitable.

In the Pauline epistles, four of the women mentioned by Paul were leaders of house churches and include Chloe (1 Corinthians 1:11), Nympha (Colossians 4:15) and Apphia (Philemon 2). Lydia, also led a Pauline house church (Acts 16). Paul also mentions in Romans (16: 6-12) that four women including Persis, Mary, Tryphena, and Tryphosa, had "worked very hard" in the Lord. When Paul employed the term "work very hard" often and in Greek this relates to gospel ministry (see inter alia 1 Corinthians 4:12; 15:10; Galatians 4:11; Philippians 2:16; 1 Timothy 4:10; see also Acts 20:35). It also relates to the work of people in authority in the Church (see inter alia 1 Corinthians 16:15-16; 1 Thessalonians 5:12; 1 Timothy 5:17). Priscilla and Aquila are spoken of in Romans 16:3-4 by Paul and they are cited six times elsewhere in the New Testament. That Priscilla is mentioned first, this indicates a higher status than her husband. Paul nominated Priscilla and Aquila as, "fellow workers in Christ Jesus," a term which he used to describe other leaders in the ministry such as inter alia, Timothy (Romans 16:21), Titus (2 Corinthians 8:23), Epaphroditus (Philippians 2:25), Clement (Philippians 4:3), Demas and Luke (Philemon 24), Apollos and even himself (1 Corinthians 3:9), and several others in Colossians 4:11 (Scholer, 1983). Phoebe is another woman affectionately celebrated by Paul to the Roman church (Romans 16:1-2). She was described as "a servant of the church in Cenchrea" and was thus a minister of the church operating in Cenchrea (Scholer, 1983/84).

Origen of Alexandria (185 - $255 \mathrm{CE})$, the early Christian scholar, ascetic, and theologian commented on Phoebe, the deaconess that was referred to by Paul in Romans (16:1-2):

This text teaches with the authority of the Apostle that even
women are instituted deacons in the Church. This is the function
which was exercised in the church of Cenchreae by Phoebe, who
was the object of high praise and recommendation by Paul...And
thus this text teaches at the same time two things: that there are,
as we have already said, women deacons in the Church, and that
women, who by their good works deserve to be praised by the
Apostle, ought to be accepted in the diaconate. (Origen,
Commentary on Romans 10:17).

Phoebe, who was praised and highly recommended by Paul. He explained her excellent service: 
who never failed to welcome guests who presented themselves, and thereby deserved one day to grant his hospitality to angels. In the same manner, likewise, Abraham, who always came forward to greet his guests, deserved to have the Lord with his angels visit him and stay under his tent. (Origen, Commentary on Romans 10:17).

On reading Acts 16:11-40 it not surprising that women leaders were able to develop themselves such as for example two women named Euodia and Syntyche, who are introduced by Paul in Philippians 4:2-3 when he says "... along with Clement and the rest of my fellow workers..." and these two "contended at my side in the cause of the gospel". In Romans 16:7, we also read of Andronicus and Junias who are termed "outstanding among the apostles". John Chrysostom accepted that although a masculine name, Junia/s, was in fact a woman (Scholer, 1983/84).

The book of 1 Timothy $2: 8-15$ is most used to offer sanctions that are very frequently cited as irrefutable by those against women preaching or teaching in the church. Nevertheless, the fundamental biblical theology of having a "new creation in Christ" in which there is "neither male and female" is a highly authoritative confirmation of the assurance to parity between men and women in the ministries of Church as servants of the Lord (Scholer, 1983/84).

\section{Gender roles in Anthropological Perspective}

An anthropological argument is used to justify the exclusion of women including widows, from priestly roles, and the usual stance is that men and women do enjoy equal value in the sight of God but this does not mean that they are in fact profoundly different to each other and have diverse and yet complementary roles to play in the church and society in general. Consequently when women are not permitted to serve as priests, it does not imply that they are inferior to men, but merely indicates that their calling lies elsewhere. The Holy Mother of God is a case in point. In Orthodoxy, it is stated "It is truly meet to bless thee, O Theotokos: Ever blessed and most pure, and the mother of our God. More honorable than the Cherubim and more glorious beyond compare than the Seraphim; who without gavest birth to God the Word, the very Theotokos: Thee do we magnify" and Mary was after all made by God a little lower than the angels, and He has crowned her with glory and honour. He made her to have dominion over the works of His hands and has put all things under her feet. She is loftier than any of the apostles, patriarchs, bishop, priests, deacons etc. but the fact remains she was not a priest (Hopko, 1982). Ware asserts "it is not correct to state that women were generally excluded from the priesthood in the ancient world... In limiting the priesthood to men, the early Church-while remaining faithful to its Judaic inheritance-was going directly contrary to the general spirit of surrounding pagan society" (Ware, 2015). He further argues "even if deaconesses are regarded as truly 'ordained,' it must not be forgotten that there is a clear distinction between the diaconate-whether male or female-and the priesthood....neither female nor male deacons have ever done is to perform the consecration at the eucharist, to bless the people, or to confer absolution" (Ware, 2015).

The feminine form of "presbyter" or elder occurs regularly, and clearly refers to women who formed an important part of the clergy. Basil the Great also termed Basil of Caesarea, a bishop of Caesarea in Cappadocia, personally took care in selecting well-meaning candidates for holy orders and he used the term presbytera in the sense of a woman who was a leader of a religious community, which did not preclude widows (Hildebrand, 2014; Costache, 2010). 
There are a few references concerning women and the likely rank of priesthood and they were often praised for their spiritual exertions. The Cappadocian Gregory the Theologian or Gregory Nazianzen, was a $4^{\text {th }}$ century Archbishop of Constantinople, and theologian, wrote to Gregory of Nyssa about a woman Theosebia, "the pride of the church, the ornament of Christ, the finest of our generation, the free speech of women, Theosebia, the most illustrious among the brethren, outstanding in beauty of soul. Theosebia, truly a priestly personage, the colleague of a priest, equally honored and worthy of the great sacraments" (Gregory of Nazianzus, Letters -Division III). We should also note that some widows deceptively abused their position by establishing businesses after receiving support. Others visited the houses of the rich in order to receive additional money donations, which they collected and then lent out at exorbitant rates (Bockman, n.d.). The order of widows disappeared entirely by the beginning of the third century in most places, although St. John Chrysostom attests to the position of widow up to the end of the fourth century. The reason for its demise was most likely that it was gradually subsumed into the office of deaconess.

There are two documents in the Orthodox Church which are in contradiction of the notion of women priests. The first one is the Declaration at the Anglican-Orthodox Joint Doctrinal Commission which was held in Athens in 1978 and the second was the Inter-Orthodox Symposium held at Rhodes in Greece in 1988. It should be noted that both of these were simply contributing to the ongoing discussion concerning women's ordination (Coyle, 1993) in the Orthodox Church. Where did this leave widows as servants of the church?

\section{Widows as clergy in the Didascalia Apostolorum (Teaching of the Apostles) -230 CE}

The early Church established an Order of Widows at the start of the $3^{\text {rd }}$ century, as is evidenced in the writings of Clement of Alexandria (Pedagogue 3:12), Tertullian (Veiling of Virgins 9, Monogamy 11) and also Hippolytus (Apostolic Tradition 11) (Beckwith, 1976). Tertullian included widows among those deemed to be clergy, but there is indeed some disagreement about their role in other writings from the early Church. Gryson, (1976) suggests that widowhood was not a clerical function but rather should be viewed an existence which enjoyed some canonical standing. On the other hand, Thurston (1989) advises that even though they did not preside in the liturgy, they were viewed as possessing a clerical rank. It is evident from literature relating to widows that any morally unfitting behaviour on their part was deemed to be unacceptable e.g., gossiping, jealousy, idleness, love of money etc, and the scope of their activities were curtailed, thus they could neither teach a religious doctrine nor baptize catechumens. Nonetheless, there was an Order of Widows, which highlights that the Church understood that widows could make a contribution to the welfare and spiritual development of fellow believers. Paul listed a range of gifts of grace and also clerical offices in the Church in 1 Corinthians 12:28, but he never suggested that these were only for males. A widow, could demonstrate by her disposition and way of life, that she had moulded herself on the example of Christ's life as one who was perfect and willing to make a sacrifice just as He had (Thurston, 1989).

The Didascalia Apostolorum which is an Ecclesiastical Constitution and legal treatise explains in detail what precisely the role of widows was in the early Church and it defines Church Orders. It was apparently written by the Twelve Apostles at the time of the Council of Jerusalem but most scholars concur that it was in fact written in Syria during the $3^{\text {rd }}$ century (Woolfenden, 2004). Epiphanius of Salamis, considered it to an Apostolic work. At the end of the fourth century the Didascalia Apostolorum was used as the foundation of the first six books of the Apostolic Constitutions. The early Christians struggled with how to develop roles for women that were in total harmony with the teachings of Christ, and which were reinforced by the anthropological assumptions prevalent at the time. The Didascalia Apostolorum makes 
available to us important references to widows as 'altar". The image of the widows as an altar of God informs us of the dynamic role played by widows as they transformed material offerings into prayers and thereby continued the relationships amongst the community and God. Two chapters are devoted specifically to widows, and they receive far more attention than any other group in the community, excluding bishops. Only bishops also had two chapters devoted to their roles. Merely one chapter was devoted to the role and conduct of deacons and deaconesses together, and in any case the deacons are deliberated on very briefly in one other chapter. The selection and duties of presbyters and deacons are discussed in only a few paragraphs in chapter which also deliberates on the election of bishops and the proper conduct expected of lay women.

The Didascalia Apostolorum thus advises that it was to an extent a common church practice that permitted women a certain degree of involvement in a delimited range of church activities so that: widows are expected to pray for the Church and deaconesses to assist at the baptism of women and also to visit Christian women in their homes to offer them spiritual support (Methuen, 1995). It was only permissible for a genuine widow who met additional criteria such as being of an advanced age and had a righteous character to be qualified to be appointed to the Order of Widows. The criteria for appointing a deaconess were more stringent than for a woman in the patriarchal world of the early Church (Hiebert, 1989). Faithfulness to Christ was a paramount consideration and taking a pledge indicated a formal association of registered widows (Moore, 2019). The pledge taken by widows to serve including their vow of celibacy was analogous of marriage (Bassler, 1996). Widows were to be good stewards of God and thus "... As good stewards of God, therefore, do well in dispensing those things that are given and come into the church according to the commandment to orphans and widows and those who are afflicted and to strangers, like men who know that you have God who will require an account at your hands, who committed his stewardship unto you" (Vööbus, 1958).

The Didascalia Apostolorum (Chapter XIV) declared that one should not appoint to the widows' order anyone that is under fifty years of age (1Timothy 5.9) because such a woman could decide to remarry due to her youth and then bring censure to the very glory of widowhood; and such a woman will need to render an account to God, first, because she has married a second husband; and then once again, because she promised to be a widow serving God, and was in any event then receiving (alms) as a widow, but did not continue in her expected widowhood. However a young woman, whose husband dies, or she becomes separated from, and she then lives alone, like a widow, she will be blessed of God; for she is like a widow will be honoured for her virtue, winning honour on earth from men, and commendation from God in heaven (Didascalia iii. 2).

It is thought-provoking to note that 1 Timothy 5 and the Didascalia Apostolorum provide diverse enrolment of widows ages. This is most likely due to a traditional stance or perhaps that the Church considered that a 50 year old widow was more able to refrain from seeking material wealth as in the case of 60 year old widows. We can surmise that variances between Paul and the author/s of the Didascalia Apostolorum on the age issue for enrolment may simply indicate the desired age range for the episcopacy in the era of the Didascalia Apostolorum.

Critically, "...she who marries one husband may lawfully marry also a second; but she who goes beyond this is a harlot (1Corinthians 7:39; Romans 7:2-3)" (Didascalia iii. 3). Bishops were called to bestow care to widows (Didascalia iii. 4).

In Chapter 15 of the Didascalia Apostolorum, it is stated how widows ought to deport themselves (iii. 5). First and foremost, a widow had to be humble, silent, gentle, without malice 
or anger; not be talkative or clamorous, or forward in tongue, or quarrelsome. And if a widow witnessed anything inappropriate done, or hears of such a deed, let her be as though she never saw or heard it. A widow should have no other care except to be praying for the whole Church. Widows were only to answer questions relating to what it meant to be righteous and faith in God. When they were questioned concerning refuting idols she was permitted to answer them, and the same applied to issues concerning the unity of God. However on issues of punishment and reward, and the kingdom of Christ, and His dispensation, no widow was permitted to speak on this since they did not possess a sound knowledge of doctrine and could most likely then bring blasphemy upon the word. When Gentiles who were being instructed, heard the word of God not fittingly spoken, by a widow they would probably mock and scoff, instead of applauding the word of doctrine; and the widow then incurs a heavy judgement for sin (iii. 6). A penitent sinner looking for reconciliation with the community and God could prostrate themselves before the widows, as well as before a male presbyter and plead with God for forgiveness for their wrongdoings to be forgiven (Gryson, 1976). Ironically, it was neither considered right nor necessary, for women to be teachers, and especially teaching about Christ since they were not appointed to this task. Widows could teach however and also pray and pray to the Lord God Jesus Christ since sent

\begin{abstract}
...the Twelve to instruct the People and the Gentiles; and there were with us women disciples, Mary Magdalene and Mary the daughter of James and the other Mary; but He did not send them to instruct the people with us. For if it were required that women should teach, our Master Himself would have commanded these to give instruction with us. But let a widow know that she is the altar of God; and let her sit ever at home, and not stray or run about among the houses of the faithful to receive. For the altar of God never strays or runs about anywhere, but is fixed in one place. A widow must not therefore stray or run about among the houses. (iii. 6. [134]).
\end{abstract}

There were also widows who received greedily and instead of doing good (works) and giving to the bishop for the entertainment of strangers and the refreshment of those in distress, they lend out the money received as usury; and they were very greedy and could not please God, or be obedient to His ministry, so as to be constantly praying and making intercession. Such widows seeking only material gain make a mockery of their prayers as all they care about is money and wealth. In Luke's gospel however, widows are described as good examples of charity and trust in God. For example, the poor widow in Luke 21:1-4 not only gave bigheartedly of all that she possessed, but showed that she trusted totally in God. Luke (7:1117 ) is interestingly the only evangelist to include the important account of the Widow of Nain. Jesus resurrects a her son from the dead, thereby reinstating the man's life and his widowed mother's life, since had he died, she would have been in dire consequences and without any provisions to sustain her.

The widows were considered to be highly susceptible and to be predisposed to poverty. Once the Temple was destroyed in $70 \mathrm{CE}$, almsgiving developed into an auxiliary for sacrifices that were offered in the Temple.

In the New Testament era, almsgiving was an important feature of worship for both Jews and Christians. Widows and orphans were the foremost recipients of alms in Jewish and Christian antiquity. In the New Testament era, the widow had functions like that of the altar, in that both the widow and the altar received sacrificial offerings dedicated to God, both the widow and the altar were expected to be kept pure, and both the widow and the altar 
functioned as a kind of "witness" between God and his people. (Moore, 2019)

A good widow who wishes to please God needs to stay at home and meditate upon the Lord day and night, without ceasing and at all times offer intercession and pray with purity before the Lord (1Timothy 5:5). She finds things to do to serve the needy and such a widow receives whatever she asks, because her whole mind is set upon this and not greed [138]. Widows must then be diffident, and obedient to the bishops and the deacons, and to reverence and respect and fear the bishop as God (iii. 8) who was the one allowed to give them permission to speak with anyone or to go to anyone to eat or drink, or even to fast with anyone, or to receive anything from anyone. They were also not permitted to lay hands on and pray for anyone without the permission of the bishop or the deacon.

Widows were advised that whatever the pastors or the deacons commanded them to do, they had to obey and do, and as such were also obeying God. It was not counselled that a woman should baptize anyone, since it was considered to be a transgression of the commandment, "... and a great peril to her who baptizes and to him who is baptized. For if it were lawful to be baptized by a woman, our Lord and Teacher Himself would have been baptized by Mary His mother, whereas He was baptized by John, like others of the people. Do not therefore imperil yourselves, brethren and sisters, by acting beside the law of the Gospel" (iii. 9 [142]).

Many women professed themselves to be widows, but did no good works worthy of their name. Some widows were accused of being jealous of older widows who had better material possessions. Equally, widows who received alms of the Lord, was required to pray for the person that provided this ministration, but was required to keep the benefactors name a secret (iii. 10) so that his or her righteousness would be with God and not with men (Matthew 6:1). When a widow gave a donation, she was expected to keep it secret from others and act in humility. Widows were to emulate bees and learn how they work. They should thus work in wisdom and her labour should be 'food' for rich and also the poor. Widows were called upon to admonish and rebuke other widow who are disobedient, and similarly encourage and help those whose comportment was right. A widow should not curse because they have been appointed to bless [146].

It is in Chapter XVI that we unpack the idea of the appointment of deacons and deaconesses [iii. 12]. A bishop was called to appoint workers of righteousness (deacons) as helpers who could co-operate with him. However, it had to be a man for the performance of most things that are required, but a woman had the solitary role of ministering to women. For example a deaconess could be sent to the home of heathens but not a deacon. Deaconesses were allowed to baptize only other women and anointed by them with the oil of anointing. If no deaconess was available to baptize a woman, a deacon could carry out this task. A deaconess could anoint the women, but a man should pronounce over them the invocation of the divine Names while they were immersed in the water. Once a woman was baptized, it was the role of the deaconess to receive her, and teach and instruct her how the seal of baptism ought to be (kept) unbroken in purity and holiness. This was considered to be acceptable since Jesus was ministered unto by women ministers, including Mary Magdalene, and Mary the daughter of James and mother of Joses, and the mother of the sons of Zebedee (Matthew 27.56). The ministry of a deaconess also included going to the houses of heathens where there were believing women, and visiting those who were ill, and ministering to them in that of which they have need to know, and they could also to bathe those who were ill.

It was incumbent that a woman deaconess be devoted to the ministry of women, and a male deacon to the ministry of men and both needed to submit themselves to the command of the 
bishop. They needed to understand the gospel and be prepared to lay down their life for their brethren in the ministry and live in a spirit of deep charity and brotherly love (John 13.14-15). Deaconesses were to minister with love, and neither murmur nor hesitate; otherwise they would have ministered as it were for the sake of men and not for the sake of God. Deaconesses and also deacons were required to visit all who were in need, and inform the bishop of all who were in distress and be totally obedient to him always [152]. Given the social circumstances of the time, it understandable that the Christian community drew upon the magnanimity of affluent women, and that it sustained a group of women who were deemed to be vulnerable (Stark, 1995). Any bishop who obtained food and clothing from those whom he serves, was intended to take care of the "deacons and widows and orphans, and those who are in want, and strangers" from any and all of the donations he received by adherents of the faith (Vööbus, 1958). There was thus some support for widows in early Christian society.

Polycarp, a Christian bishop of Smyrna, in his Epistle to the Philippians mentions that widows are an 'altar of God'. What he uttered is significant since he was an elder of a significant congregation that was a large contributor to the establishment of the Christian Church (Kirby, 2020). Tradition identifies Ignatius, Bishop of Antioch; along with his friend Polycarp, as disciples of John the Apostle (O'Connor, 1910). In an Epistle to Polycarp, Ignatius counselled Polycarp to "Let the widows be not neglected; after the Lord, you shall be their guardian. Let nothing take place without your approval; nor do you anything without God, which indeed you do not; stand firm." (Howell, 2009).

\begin{abstract}
Twice Ignatius sent greetings to Alce, whom he calls especially dear to him. He also greeted Tavia and her household; perhaps she was another house-church leader. Polycarp mentioned the sister of Crescens, who deserved special commendation when she and her brother arrived in Philippi to deliver the letter. The Shepherd of Hermas, written about 148 A.D., gives instructions that two copies should be made of the work and one given to Grapte, "who shall exhort the widows and orphans." The other copy was to be given to Bishop Clement to share with the elders. It appears that Grapte and Clement represented the female and male leaders respectively. (Kroeger, 1988)
\end{abstract}

The duties of widows, irrespective of being enrolled or not included praying, teaching women, and undertaking good deeds. They were not permitted to function in any explicitly male roles. They were not to answer questions relating to theological issues nature, but had to refer these to the leaders of the community, men in official positions. Widows were still respected such that malefactors needed to prostrate themselves in the centre of the assembly in front of widows and male presbyters. Numerous Alexandrian writers recorded widows along with the bishops, presbyters, and deacons but widows were appointed, and never ordained and so there was no laying on of hands accompanied by prayer for them (Bockman, n.d.)

\title{
Conclusion
}

In the latter part of the $3^{\text {rd }}$ century third the Order of Widows began to decline and was progressively replaced by an Order of Virgins although it was accepted that young virgins could be admitted to the order of widows. There were Church leaders who criticized this practice since it debased the requirements that a widow be at least sixty years of age, a mother, and ideally a woman who had educated her own children. Ultimately the Order of Virgins was incorporated into women's monasticism at the start of the $4^{\text {th }}$ century. One of the best-kept secrets from early Christianity is the huge role that widows played in the early church. 
In Christianity how well women have been treated and how much equality has been articulated by culture seems to have varied significantly under diverse circumstances and historical contexts of the faith. Jesus teachings and message diverged somewhat from the prevailing cultural patterns in his high estimation of women. Despite widows being able to serve as ministers in the faith women in the early Church, for the most part they remained undervalued. There were however inter alia, numerous women as described in this article who were highly regarded and who played significant roles in the Church in their particular communities, even though they were not apostles. These women were to an degree viewed as possessing an intrinsic dignity and commanded a fundamental respect because they were pious and since men and women are created in the Imago dei, this should not be surprising. The Didascalia Apostolorum allows to understand fully what widows represented in the Syriac communities of the 3rd century. There were widows and also widows who were appointed. Widowhood was clearly a privileged chance to advance spiritually in the Didascalia Apostolorum, the key considerations appear to be prayer and a vow of continence. In addition, any widow and could qualify for support from a bishop or cleric, and this did not necessitate them being enrolled in the Order of Widows. It was via the Order of Widows, that the early Church recognized the important contribution that widows could make in enhancing the spiritual development and well-being of adherents to the faith. By means of this order, the early Church then demonstrated its understanding as it permitted widows, albeit, in a limited fashion, to render service to the community and promote some social cohesion.

The early Church distinguished itself from the wider pagan ethos pervading the GraecoRoman world by demonstrating its concern for widows and how to employ them in rendering service to God. The article offers us a better understanding of widows as God's servants establishing a vital association between a community and God. It is clear from the roles played by women in the first century Church that their functions were far more extensive and formal than is the current practice in numerous church denominations. This brief article hopefully enables the reader to develop a great understanding of early Christian widows as consecrated women, serving the Church and God, and the value that they add to the faith. There is indeed a great deal more to learn about women as pillars of the Christian faith.

\section{References}

Ambrose, Concerning Widows, Translated by H. de Romestin, E. de Romestin and H.T.F. Duckworth. From Nicene and Post-Nicene Fathers, Second Series, Vol. 10. Edited by Philip Schaff and Henry Wace. Buffalo, NY: Christian Literature Publishing Co., 1896.Revised and edited for New Advent by Kevin Knight. [Available online at http://www.newadvent.org/fathers/3408.htm].

Barnes, T. (2011). Constantine: Dynasty, Religion and Power in the Later Roman Empire, Oxford: Wiley-Blackwell.

Basil of Caesarea (1930). Saint Basil: the Letters, Letter 199. Edited I. Defarrari (ed.), London.

Bassler, J.M. (1996). 1 Timothy, 2 Timothy, Titus, Nashville: Abingdon Press.

Beckwith. R. T. (1976). "The Office of Woman in the Church to the Present Day," in M. Bruce and G. E. Duffield (eds.), Why Not? Priesthood and the Ministry of Women, Abingdon, Berks: Marcham. 
Bockman, V. (n.d.). The Role of Women in the First Century Church as a Model for Today, Part 2: Orders for Ordinary Christian Women, The Saints. [Available online at http://orthodoxyinfo.org/women.htm]

Botte, B. (1946). La Tradition Apostolique de S. Hippolyte, SChr 11, Paris.

Bradshaw, P. (2012). Women and Baptism in the Didascalia Apostolorum, Journal of Early Christian Studies, 4(4), (Winter 2012).

Campbell, J.C. (2009). Phoebe: Patron and Emissary, Collegeville, MN: Liturgical Press.

Clark, E. A. (1986). Adam's Only Companion: Augustine and the Early Christian Debate on Marriage, Recherches Augustiniennes et Patristiques, 21, 139-162.

Clement of Alexandria, Commentary on 1 Corinthians 9:5, Stromata 3,6,53.3-4.

Connolly, R. H. (1929). Didascalia Apostolorum: The Syriac Version Translated and Accompanied by the Verona Latin Fragments, Oxford, UK: Clarendon Press.

Costache, D. (2010). Christian Worldview: Understandings from St Basil the Great, Phronema, 20, 21-56.

Coyle, J. K.. (1993). The Fathers on Women and Women's Ordination, In Women in Early Christianity, Edited by David M. Scholer, New York: Garland Publishing.

Davies, J. G. "Deacons, Deaconesses, and the Minor Orders in the Patristic Period." In Church, Ministry, and Organization in the Early Church. Edited by Everett Ferguson, 237-51. New York: Garland Publishing, 1993.

Davis, W. H. (2005). Beginner's grammar of the Greek New Testament, New York: Harper \& Row Publishers.

Dei, D. \& Osei-Bonsu, R. (2015). The Female Ordination Debate: Theological Reflections, Asia-Africa Journal of Mission and Ministry, 11, pp. 31-62,

Evdokimov, P. (1994). Woman and the Salvation of the World: A Christian Anthropology on the Charisms of Women, New York: St. Vladimir's Seminary Press:

Gregory of Nazianzus, Letters (Division III), Translated by Charles Gordon Browne and James Edward Swallow, Nicene and Post-Nicene Fathers, Second Series, Vol. 7. Edited by Philip Schaff and Henry Wace. (Buffalo, NY: Christian Literature Publishing Co., 1894.) Revised and edited for New Advent by Kevin Knight. [Available online at http://www.newadvent.org/fathers/3103c.htm].

Gregory of Nyssa, Migne PL 46, cols 988-990.

Grenz, S. J. \& Muir Kjesbo, D. (1995). Women in the church : a biblical theology of women in ministry, Downers Grove, III: InterVarsity Press.

Gryson, R. (1976). The ministry of women in the early Church, J. L. Laporte and M. L. Hall, (Trans.), Collegeville, MN: The Liturgical Press. 
Hammer, T. (2009). Wealthy Widows and Female Apostles: The Economic and Social Status of Women in Early Roman Christianity, in G.D. Dunn, D. Luckensmeyer \& L. Cross (ed.), Prayer and Spirituality in the Early Church: Poverty and Riches, 5, Strathfield: Paulist Press,

Heine, R. E. (2010). Origen: Scholarship in the Service of the Church, Oxford, England: Oxford University Press.

Hiebert, P. (1989). "Whence shall help come to me? The biblical widow". In Gender and difference in ancient Israel, Edited by: Day, Minneapolis: Fortress Press.

Hildebrand, S.M. (2014). Basil of Caesarea, Grand Rapids: Baker Academic.

Holy Bible -New King James Bible

Hopko, T. Ed. (1982). Women and the Priesthood, Crestwood NY: St Vladimirs Seminary Press.

Howell, K. J. (2009). Ignatius of Antioch and Polycarp of Smyrna: A New Translation and Theological Commentary, Zanesville, OH: CHResources, 2009

John Chrysostom, Migne PG - Patrologiae Graecae, 62, col. 553.

Johnson, A. F. (2006). A Meta-Study of the Debate over the Meaning of 'Head' (Kephale) in Paul's Writings, Priscilla Papers, 20(4), Autumn.

Karras, V. A. (2004). Female Deacons in the Byzantine Church, Church History, 73(2), 272316.

Kirby, P. (2020). St. Polycarp of Smyrna, Early Christian Writings [Available online at www.earlychristianwritings.com/polycarp.html]

Kroeger, C. (1988). The Neglected History of Women in the Early Church, Christian History Issue 17. [Available online at https://christianhistoryinstitute.org/magazine/article/women-inthe-early-church]

Lee, D. A. (2021). The Ministry of Women in the New Testament: Reclaiming the Biblical Vision for Church Leadership, Grand Rapids: Baker.

Leonhard O.S.F., B. (2006). St. Paul and Women: A Mixed Record, St. Anthony Messenger: Franciscan Media.

Martimort, A.G. (1986). Deaconesses: An Historical Study, Translated by Kenneth D. Whitehead, San Francisco: Ignatius Press.

McCarty, V. K. (2010). Phoebe as an Example of Female Authority Exercised in the Early Church, presented at The Sofia Institute, Third Annual Conference, Union Theological Seminary Campus, NY.

Meeks, W.A. (2003). The First Urban Christians: The Social World of the Apostle Paul, Yale University Press 
M. Cathleen Kaveny (2005). The Order of Widows: What the Early Church Can Teach Us about Older Women and Health Care, Christian Bioethics, 11(1), 11-34.

Methuen, C. (1995). Widows, Bishops and the Struggle for Authority in the Didascalia Apostolorum, The Journal of Ecclesiastical History, 46(2), 197-213. doi:10.1017/S0022046900011337

Methuen, C. (1999). The Virgin Widow: A Problematic Social Role for the Early Church?, Christianity and Society: The Social World of Early Christianity, Edited by Everett Ferguson, 63-76. New York: Garland Publishing.

Moore, L. M. (2019). "Widow As the Altar of God: Retrieving Ancient Sources for Contemporary Discussions on Christian Discipleship". Dissertations (1934 -). 876. [Available online at https://epublications.marquette.edu/dissertations_mu/876]

Nicolaides, A. (2021). Investigating the Holy Eucharist and the term 'people of God' according to the Eastern Orthodox Church, Pharos Journal of Theology, Volume 102.

Nicolaides, A. (2014). The Philosophical Conception of Mariology and the notion of the Theotokos in the teachings of saint Ambrose, Phronimon,15(2).

Nicolaides, A. (2010). The Laos tou Theou - an orthodox view of the "people of God", HTS Teologiese Studies/Theological Studies 66(1), DOI: 10.4102/hts.v66i1.372

O'Connor, J.B. (1910). St. Ignatius of Antioch, The Catholic Encyclopedia Vol. 7. New York: Robert Appleton Company.

Onumah, J.M. \& Nicolaides, A. (2021). Human Rights and Eastern Orthodox Understanding and Teachings for a Troubled World, Pharos Journal of Theology, Volume 102.

Origen. Commentary on Romans 10:17, Migne PG- Patrologiae Graecae XIV col. 1278 A-C.

Pagels, E. (1989). Adam, Eve, and the serpent: Sex and Politics in Early Christianity, New York: Vintage Books.

Pelikán, J. (1987). The excellent empire: the fall of Rome and the triumph of the church, San Francisco: Harper \& Row.

Polycarp. (2003). To the Philippians. Edited and translated by Bart D. Ehrman. In The Apostolic Fathers, Cambridge, Mass: Harvard University Press.

Quinn, J. D. \& Wacker, W.C. (2000). The First and Second Letters to Timothy: A New Translation with Notes and Commentary, Grand Rapids, MI: William B. Eerdmans.

Reid, B. (1996). Choosing the Better Part? Collegeville: Liturgical Press.

Scholer, D. M. (1983/1984) Women in Ministry (adapted), The Covenant Companion, December 1, 1983; December 15, 1983; January 1984; and February 1984 issues. [Available online at https://www.fuller.edu/womeninministry/] 
Seim, T.K. (1994). The Double Message: Patterns of Gender in Luke-Acts, Edinburgh: T \& T Clark Ltd.

Stark, R. (1995). Reconstructing the rise of Christianity: The role of women, Sociology of Religion, 56(3), 229-244.

Stewart, A. C. (2015). On the Apostolic Tradition, Hippolytus, an English version with introduction and commentary: 2nd edition, St Vladimir's Seminary Press.

Swan, L. (2001). The forgotten desert mothers : sayings, lives, and stories of early Christian women, New York: Paulist Press.

Thurston, H. (1908). "Deaconesses." The Catholic Encyclopedia. Vol. 4. New York: Robert Appleton Company.

Thurston, B. B. (1989). The widows: A woman's ministry in the early Church, Minneapolis: Fortress Press.

Tyson, J.B. (1992). Images of Judaism in Luke-Acts, Columbia, SC: University of South Carolina Press.

Vööbus, A. (1958). History of Asceticism in the Syrian Orient, Louvain: Secrétariat du Corpus SCO.

Ware, T. (2015). On the Ordination of Women in the Orthodox Church, Agnostic Christianity, [Available online at https://newenglandsun.wordpress.com/2015/01/08/met-kallistos-ware-onthe-ordination-of-women-in-the-orthodox-church/]

Warfield, B. B. (1919). Women speaking in the Church, The Presbyterian, Oct. 30,

Wessel, K.C. (2017). Charity towards Widows in Early Christian Communities, University of Florida, Degree of Doctor of Philosophy [Available online at https://ufdcimages.uflib.ufl.edu/UF/E0/05/10/37/00001/WESSEL_K.pdf]

Wharton, A. (1987). Ritual and Reconstructed Meaning: The Neonian Baptistery in Ravenna, Art Bulletin, 69(3), 358-375.

Woolfenden, G. W. (2004). Daily liturgical prayer: origins and theology, Ashgate Publishing.

Zamfir, K. (2013). Men and Women in the Household of God: A Contextual Approach to Roles and Ministries in the Pastoral Epistles, Vandenhoeck \& Ruprecht GmbH \& Co. KG, Göttingen. 